\title{
Gifting Knowledge for Long Life
}

\section{Anthony Cerulli}

International Journal of Hindu Studies

ISSN 1022-4556

Volume 22

Number 2

Hindu Studies (2018) 22:235-255

DOI 10.1007/s11407-018-9229-1

\section{International Journal of}

\section{HINDU STUDIES}

Edited by

Sushil Mittal

Special Issue: The Gift in India in Theory and Practice

Springer

ISSN: 1022-4556 
Your article is protected by copyright and all rights are held exclusively by Springer Nature B.V.. This e-offprint is for personal use only and shall not be self-archived in electronic repositories. If you wish to self-archive your article, please use the accepted manuscript version for posting on your own website. You may further deposit the accepted manuscript version in any repository, provided it is only made publicly available $\mathbf{1 2}$ months after official publication or later and provided acknowledgement is given to the original source of publication and a link is inserted to the published article on Springer's website. The link must be accompanied by the following text: "The final publication is available at link.springer.com". 


\title{
Gifting Knowledge for Long Life
}

\author{
Anthony Cerulli
}

\begin{abstract}
During nonemergency appointments at traditional sites of āyurvedic healthcare in Kerala, South India, classically trained Brāhmaṇa physicians and their patients seldom exchange anything of substance (whether medicinal or monetary). The physician-patient interface instead routinely involves an exchange of knowledge. Interactions between physicians and patients in these meetings evoke the highly theorized notion of the "Indian gift" and the question of prestation in South Indian societies. This article explores the nature of exchange in the supply and reception of healthcare among physicians and patients at traditional sites of āyurvedic treatment (that is, sites not affiliated with governmental or private hospitals or clinics) in contemporary Kerala. Drawing on classical treatises about the dharma of gifts (dānadharma) and the Sanskrit medical classics of Āyurveda, it examines reciprocity, ideal preconditions of givers and receivers of gifts, and the possibility of a "pure gift" in the appraisal and production of wellbeing.
\end{abstract}

Keywords Āyurveda · dānadharma · "Indian gift" · reciprocity · physician-patient encounter $\cdot$ Kerala

\section{Introduction}

At Mookkamangalam - a clinic in central Kerala run by classically trained physicians of Āyurveda-nonemergency healthcare seldom involves an exchange of material things. ${ }^{1}$ Patients commonly do not receive medicine for their disorders;

\footnotetext{
1 To ensure the anonymity of the people mentioned in this article, all proper names drawn from my fieldwork have been pseudonymized.
}

Anthony Cerulli

acerulli@wisc.edu

University of Wisconsin-Madison, Madison, Wisconsin, USA 
physicians routinely receive no payment for their services. Information is the only thing that appears to pass between physicians and patients at this āyurvedic clinic, and it flows in a conversational, if semiformulaic manner, akin to clinical communications I have had as a patient of biomedical doctors in the United States. The information exchanged at Mookkamangalam characteristically and unsurprisingly deals with patients' experiences of illness and physicians' appraisals of patients' bodies and how to treat them.

The interchange of somatic information at Mookkamangalam between physicians, called vaidyans in Malayalam, ${ }^{2}$ the language of Kerala, and their patients, known as rogis, calls to mind Marcel Mauss's classic illustration of gift exchange in "Essai sur le don: forme et raison de l'échange dans les sociétés archaïques" (192324; hereafter The Gift). ${ }^{3}$ Namely, a contractual do ut des appears to be in play: the patient gives to the physician so that the physician might give something back to the patient; likewise, the physician gives to the patient so that the patient might, in the end, give something back to the physician. In the medical marketplace, after a patient presents an illness and its history, we expect a physician to respond by giving something to the patient, such as a diagnosis and prognosis. When the physician then gives medicine or a prescription to the patient, this act prompts yet another offering from patient to physician, commonly in the form of a payment. With that, the exchange usually ends agreeably; both parties leave having fulfilled their obligations in this particular social relationship. Mookkamangalam presents a slightly different scenario, however. A medical marketplace in the generic sense, this clinical space deals almost exclusively in the exchange of knowledge, and the exchanges of physicians and patients are designed to be unequal and nonreciprocal. With Mauss's theory of the gift as a prompt, this article reflects on the motivations, justifications, and rewards of giving and receiving knowledge in the clinical dealings of āyurvedic physicians and their patients in central Kerala.

In the United States a gift colloquially designates a one-sided offering. A gift giver presents a person with something that's seen neither as a reciprocation for an earlier exchange nor as an offering meant to bring about a future return on the part of the recipient. Participants in these exchanges might perceive themselves as givers or receivers of so-called free gifts - offerings given unmotivated by self-interest or an expectation of future recompense. Often, however, due to time lags between initial and counter gifts, people tend to forget or overlook the quid pro quo understandings of which their "gifts" are a part; or because profit interests of givers are sometimes veiled in fields of euphemism (Bourdieu 1998: 115), the reality of free gifts is in fact imaginary. Gifts aren't really free, Mauss argued. Free gifts are not and haven't been part of exchange economies in most human societies. So, after a physician gives a prescription or medication to a patient, a counter offering is ordinarily given from patient to physician, leveling the relationship according to symmetrical prestations. Interactions between physicians and patients at

\footnotetext{
${ }^{2}$ In Sanskrit, the standard designation for a physician of Āyurveda is vaidya; the terms bhisaj and cikitsaka also denote a similar medical practitioner in the Sanskrit medical classics (Olivelle [2017] parses these three titles thusly: bhis $a j=$ physician; cikitsaka $=$ medic; vaidy $a=$ doctor).

${ }^{3}$ All references to the abbreviated English title, The Gift, refer to W. D. Hall's 1990 English translation: The Gift: The Form and Reason for Exchange in Archaic Societies.
} 
Mookkamangalam destabilize this design. The physician-patient relationship is based on asymmetrical exchange in which a physician gratuitously gifts to a patient "knowledge for long life" (the literal translation of the Sanskrit term, ayurveda). ${ }^{4}$ The patient does not compensate the physician for this gift, for, if one follows the roughly two thousand-year-old teachings in the Sanskrit medical classics, an exchange of equal prestations in the āyurvedic context runs the risk of being invalid.

In the exchange system of classically trained Malayā $\bar{l} i^{5}$ physicians and their patients, the Maussian gift is at once validated and rendered problematic. Mauss argued in The Gift that an obligation to reciprocate an offering, whether immediately or at a later time, is a regular facet of archaic societies. With this general observation and his theorization of the forms and reasons for exchange, he intended his study to present a prehistory of economic and legal contracts that are found in most modern societies as well (Mauss 1990: 47-64). Notwithstanding the theory's overall veracity in the contexts of both archaic and modern human societies, exchange in the Indian context-seen in classical Indian literatures as well as modern ethnographies - often deviates from Mauss's theory. For example, the Sanskritic notion of dānadharma - the duty (dharma) of giving (dāna) - does not permit reciprocity. The back and forth movement characteristic of exchange economies in Mauss's analyses is anathema to classical Indian gift giving, or dāna. A kind of expiatory gift given to someone specifically authorized to receive it, proper dāna establishes neither an obligatory bond nor an equal relationship between giver and receiver. Axel Michaels has suggested that, "wherever reciprocity is practised, it is not a case, in India, of religious dānāni [that is, gifts] but of profane exchange or trade" (1997: 244). Reciprocal exchange (what Michaels calls profane exchange or trade) in India does not amount to dāna, though it accords with Mauss's model of exchange, whereas the nonreciprocal gift giving of dāna is inimical to that model.

Mauss was aware that the history and practice of dāna in India posed challenges to his ideas about exchange. In W. D. Hall's English translation of The Gift, Mauss's most telling reflection on the "Indian gift" is contained in the now-famous footnote 61. There Mauss draws on passages from classical Sanskrit literature, including the Mahābhārata and Hindu treatises on religious propriety, ethics, and law (collectively known as Dharmaśāstra literature), which forbid the reciprocation of certain gifts (dānāni), especially gifts given to Brāhmaṇas. Footnote 61 contains the following lengthy comment about the outlier status of the Indian gift:

Concerning the main subject of our analysis, the obligation to reciprocate, we must acknowledge that we have found few facts in Hindu law, except perhaps Manu, VIII, 213. Even so, the most apparent fact is the rule that forbids reciprocity. Clearly, it seems that originally the funeral çraddha [sic-read: śrāddha], the feast of the dead that the Brahmins expanded so much, was an

\footnotetext{
4 A distinction is made in this article between Āyurveda and āyurveda: the former (with an upper case $\bar{A}$ ) is the proper name of the classical Indian medicine, while the latter (with a lower case $\bar{a}$ ) is that (knowledge for long life) which physicians of Āyurveda give to their patients.

5 The term "Malayāḷi" designates someone from a Malayalam-speaking community, usually someone from the southwestern Indian state of Kerala.
} 
opportunity to invite oneself and to repay invitations. But it is formally forbidden to act in this way, for example [in the Anuśasanaparvan of the Mahābhärata]...: "He who invites only friends to the çraddha [sic] does not go to heaven. One must not invite friends or enemies, but neutral persons, etc. The remuneration of the priests offered to priests who are friends is called demoniacal (picaca) [sic_read: piśāca]." ...The cunning Brahmins in fact entrusted the gods and the shades with the task of returning gifts that had been made to themselves. Undoubtedly, the common mortal continued to invite his friends to the funeral meal. Moreover, this continues in India in the present day. For his part, the Brahmin did not return gifts, did not invite, and did not even, all said and done, accept invitations. However, Brahmin codes have been preserved in sufficient documents to illustrate our case (Mauss 1990: 146-47).

Mauss acknowledged in 1923-24 that the prohibition against the repayment of gifts "continues in India in the present day." This observation speaks to the social tenacity and dogged authority of classical texts and practices designed to uphold dharma, most notably The Laws of Manu and the custom of dāna, in India in modern times. Yet as the āyurvedic example from Kerala illustrates, Sanskritic commands are rarely reified wholesale in practice in the present day. Even if the spirit of dhārmic law persists in the present, the letter of that law might not.

To analyze knowledge as gift (or, the idea of gifting knowledge), it's instructive to observe, as Miriam Benteler recently suggested (2014: 273), that gift exchange consists of far more than material gifts. It also encompasses intangible things like ideas and ritual participation, all of which support certain social roles and relationships. By exchanging knowledge about the body, physicians and patients at Mookkamangalam are poised on the threshold of an exchange economy that has features of profane trade, involving a classic do $u t$ des, as well as features of an asymmetrical social relationship typical of the Indian gift (dāna). Although it exhibits aspects of asymmetrical gifting, aspects not noted in footnote 61 of The Gift, thus both challenging Mauss's theory and affirming the uniqueness of the Indian gift, the Mookkamangalam case also adds conceptual nuance to, and encourages further analytical elaboration of, the ways in which scholars have imagined gift giving as entirely atypical in India. In what follows, I propose that the gifting of knowledge for long life at a traditional clinic of Āyurveda in central Kerala challenges and problematizes research on gift theory in Indian Studies and Indology, since Mauss's classic analysis, that tends to treat dāna as incontrovertibly rigid and "by the book" (that is, in step with classical Dharmaśāstra literature).

\section{Physicians and Patients}

The vaidyans who run Mookkamangalam clinic are Nambūtiri Brāhmaṇas. They represent three generations - grandfather/father, daughter/mother, and grandson/sonin a family that has transmitted a variety of Āyurveda unique to the central Kerala region for over five generations. By referring to them as classically trained, I wish to 
underscore two things: first, because they have not received official degrees from Ayurvedic Colleges, the Government of India has not licensed these physicians to practice Āyurveda; second, rather than the mixed āyurvedic-biomedical course of study found at Ayurvedic Colleges in India today, these physicians have undertaken studies and apprenticeships that focus on the memorization and clinical use of the Sanskrit medical classics, especially the Aștāingahrdayasamhitā (circa seventh century $\mathrm{CE}$ ). The space that I refer to as the clinic at Mookkamangalam is not a special area designated for seeing patients, but is part of the residential grounds where the mother and son currently live. Each vaidyan attends to rogis from diverse socioeconomic and religious backgrounds. A rogi could be a young child, middleaged man or woman, or a senior citizen. Most rogis who visit the clinic are local, coming from the same neighborhood or district, though some travel distances as far as an hour away. During a normal week, vaidyans see anywhere from five to twelve rogis per day, and the vaidyan-rogi encounter has the appearance of being seamlessly woven into the fabric and activities of the physicians' daily lives and other obligations. Clinical visits are interspersed amid domestic chores like cooking, cleaning, animal husbandry, harvesting mangoes and rice, washing clothes, entertaining visitors, teaching tyro-vaidyans, and the like.

On a typical visit, rogis and their companions-family members most often, but sometimes also neighbors or friends-ordinarily reach the multiple-building compound of Mookkamangalam by taxi, auto-rickshaw, motorcycle, or on foot. Since there are no visible signs or markers delineating a clinical space on the compound, rogis and their attendants make their arrival known as most visitors to a traditional Nambūtiri residence would: they audibly announce their presence or knock on the door of the residential building (known as the mana or illam). Then they wait on the veranda until someone greets them. Oftentimes a whistle or discreet signal from one of the workers milling about the property relays the news of a patient's arrival to someone inside the house, who informs the vaidyan on-call that day. After the vaidyan receives the strangers, the rogi and her companions present a collective story about what's wrong. Mookkamangalam's vaidyans specialize in the treatment of skin disorders and snakebites, both of which are commonly translated into English using the biomedical category "toxicology" (from the Sanskrit visacikitsā). Most rogis who visit Mookkamangalam present cases of contact dermatitis, allergic rashes caused by diet, and inflammatory reactions to insect and spider bites. More severe and potentially fatal cases, to which I return momentarily, involve sickness and trauma due to snakebite.

In recent years Mookkamangalam has opened its doors to āyurvedic students outside of the immediate family line who profess an interest to learn "traditional Āyurveda." 6 Thus a rogi visiting Mookkamangalam nowadays often reveals his conditions in a teaching environment. The Malayalam term (derived from Sanskrit) normally used to designate this didactic component is gurukulam-“family [house] of the teacher." Today, gurukulam is something of a catchall that indicates both

\footnotetext{
${ }^{6}$ Most of the students I have met over the last decade at Mookkamangalam use this phrase to designate Sanskrit-based Āyurveda instead of the modern Āyurveda-biomedicine blend they claim to learn at the Ayurvedic College.
} 
hands-on journeyman training and an intimate classroom relationship between a teacher and a student (hence it's sometimes described in Sanskrit as guruśisyasambandham, "teacher-student connection"). ${ }^{7}$ I have observed anywhere from one to six students shadowing and assisting a vaidyan at Mookkamangalam (who is usually also the students' guru) as he or she makes diagnoses and prescribes medicines and treatments. The students' participation resembles the activities of medical students at teaching hospitals in the United States. They accompany an attending physician to see patients, and they respond to questions the attending physician puts to them about the various cases they encounter. The current principal vaidyan at Mookkamangalam (the grandson/son) customarily quizzes his students while attending to a rogi. Following a rogi's testimony, he asks his students to draw connections between their observations of the illness(es) presented and their textual studies in the gurukulam, which at Mookkamangalam has always been and continues to be an intensive study of āyurvedic literature written in Sanskrit, especially the Aștāingahrdayasamhitā, and Malayalam and Manipravalam works on poison treatment, such as the Jyōtsnika and the Kriyākaumudi. Traditionally, students at Mookkamangalam memorize, recite, and analyze these texts with the cardinal aim of clinical application, and on most days there appears to be seamless continuity between gurukulam textual training and clinical treatment of patients. Students are taught to cite passages from the Aștāingahrdayasaṃitā and Malayalam works that they think are germane to each patient, and vaidyans go to great lengths to ensure the connections students draw between text and practice are accurate and useful.

After learning the reasons for a rogi's visit, the vaidyan responds with a series of questions. Sometimes these questions are put directly to the rogi and other times to the rogi's attendants (depending on such things as the rogi's age, level of anxiety, and severity of sickness); his interrogation is intended to establish the location of the rogi's residence, profession, dietary habits, elimination regularity, and family health history. Once a rogi and her attendants have answered these questions, the vaidyan responds with a commentary about what he perceives the issue to be, and he discusses whether or not it can be treated. He might ask one of his advanced students to try to do this first, after which he corrects and/or adds nuance to the student's diagnosis, replete with references to the Aștāingahrdayasamhitā and other relevant sources. The vaidyan then recommends a plan to treat the disorder. This plan, loosely translated as a "prescription," is a brief memorandum or command called a kurippati. A kurippați may be conveyed orally but is often written down so the rogi can consult it again at a later time. It usually amounts to a list of herbs, plants, and powders for purchase at the market and instructions for cooking the

\footnotetext{
7 In Kerala, historically what's called a gurukulam today is related to the eluttupalli, or "village school." Eluttupall is were originally intended for the education of non-Brāhmaṇa male and female youths, whereas other, much larger institutions like the ninth-twelfth centuries salai and early medieval sabha mutt (religious temple-centers of learning) were reserved for Brāhmana youths with the highest scholastic abilities. Under the guidance, and typically at the house, of an eluttacchan or äśān (teacher), students in eluttupallis took lessons in basic subjects like reading, writing, arithmetic, and more advanced humanistic and technical subjects, such as kavya, nātakas, nyāya, vyākārana, and āyurveda. Menon's research suggests the establishment of western-style educational centers in Kerala in the nineteenth-century for all intents and purposes signaled the death knell of the Malayāli eluttupaḷi (1979: 280-321).
} 
ingredients into a decoction for consumption and recommended daily doses. With that, the technicalities of the meeting are over. Sometimes conversation carries on with small talk, especially if the visitors have been to Mookkamangalam before or mutual friends have referred them to the clinic, before the patient and her companions depart.

In some cases follow-up appointments are set for days, weeks, or even months later. But more often than not, a return check-up is considered unnecessary unless the problem gets worse or persists beyond a certain time. Because a rogi and her attendants have been equipped with information needed to correct her ailment, after taking leave of the clinic they can reprocess the knowledge the vaidyan gave them should the malady resurface. Numerous times during my fieldwork at Mookkamangalam, rogis or their attendants have inquired about the fee for the vaidyan's time, diagnosis, and prescription. Each time the answer is that all services are provided saujanyamāyi, "for free." Nevertheless many rogis thrust payment at the vaidyan or diplomatically ask his students to take their money. Irrespective of their persistence, Mookkamangalam's vaidyans insist on accepting nothing-no money or goods-for their services. Even in cases where medicine (aușadham) is dispensed on site to a rogi, the same policy about remuneration holds true.

When medicines are administered during a vaidyan-rogi meeting, the give-andtake between the two is rather fraught. The fact that drugs are needed indicates that a rogi is seriously ill. A snakebite victim presents perhaps the most common emergency situation at Mookkamangalam requiring immediate treatment. A person who has been bitten by a venomous snake might arrive at the clinic in a semiconscious state, be lethargic or nonresponsive, or very agitated. In any of these circumstances the offering of drugs initiates a much more elaborate form of social interaction than a routine meeting does. The vaidyan responds to the snakebite victim's arrival by swiftly retrieving medicinal plants from the yard and prepared drugs from the dispensary, and he ensures the rogi takes the drugs he apportions correctly and straightaway. Even when they prepare the drugs themselves in emergency situations, vaidyans at Mookkamangalam almost never apply the oils, pastes, or other topical medicines themselves or in any way touch a rogi. Deliberately avoiding the putative dangers of polluting contact, they instruct the rogi's attendants to administer the drugs. Even during nonemergency cases, physical contact between a vaidyan and a rogi at Mookkamangalam is rare. The absence of contact is compatible with the nature of Mookkamangalam's gifting system, where the polestar of a clinical visit is knowledge. Maintaining physical separation also speaks to the roles the clinic's vaidyans envision for themselves in the gifting of knowledge for long life.

An illuminating parallel can be seen in the practice of blood donation (rakt dān in Hindi) in North India. Analyzing rakt dān as a gift economy, Jacob Copeman suggests that a physician's orchestration of medical services for patients, especially in emergency situations, objectifies and makes explicit "those always-present and yet at the same time frequently latent fears concerning the flows of bio-moral qualities between persons." In medical contexts dāna brings people "fully face-toface with the dangers of social contact" (Copeman 2011: 1059). A vaidyan's gift of ayurveda to an ailing rogi without contact evokes the typology of purity and 
pollution that has occupied scholars of Indian religions for decades. It also raises questions about the tenuousness of the medical profession for high class Brāhmanas, since this work routinely requires the physician to interact with people considered to be polluted. That the vaidyans at Mookkamangalam treat rogis without touching them could be seen as a way for these Nambūtiri Brāhmaṇas to practice Āyurveda while also upholding their religious injunction to remain ritually clean, uncontaminated by polluting substances associated with the body like pus, blood, mucus, sweat, saliva, and hair. In his classic, albeit also contested, articulation of Indian conceptions of purity and pollution, McKim Marriott (1976) argued that people are exposed to a constant barrage of "substance-codes" that flow from person to person in the course of regular interactions. On this view, the unease of the vaidyan in the face of a seriously ailing rogi could be seen as part of a conscious effort to avoid aspects of an exchange system typical of physician-patient encounters. Mookkamangalam's vaidyans hold to the titular letter of the knowledge system they practice, exchanging only the most abstract and subtle substances that Marriot claimed make every person in the Indian imagination dividually porous, rather than individually contained. Namely, they deal exclusively in "knowledge" (veda) as a means to ensure "long life" (ayus). As a subtle and powerful form that's exchanged via words, ideas, and appearances even knowledge is imbricated in the constant transfer and entanglement of particles and assorted matter moving between people. These exchanges, Marriott reasoned, are what make people dividual, "always composites of the substance-codes that they take in" day-to-day (1976: 111). Gifting knowledge as medicine might not result in overt contamination. It does, however, contribute to the continual reconstitution of both the gift giver and gift receiver.

Another example from North India provides a useful lens through which to understand the form and function of the gift at Mookkamangalam. In North India the Hindi expression aușadh dān, "gift of medicine" (Sanskrit, aușadha dāna), frequently indicates a form of charitable giving to the indigent (Agarwal 2010: 100). Auṣadh dān functions as a combined social-medical-religious practice that alleviates medical issues (physical and financial) and absolves sins. Ron Barrett's (2008) study of Aghorī doctors at Varanasi's Kushth Seva Ashram presents a vivid case of aușadh dān. Aghorī doctors at the Ashram give their socially outcast patients with leprosy, leukoderma, and vitiligo, diseases often seen as the result of grave improprieties, a potent mix of medicines and blessings (davā aur duā in Hindi). By physically embracing their patients, they also challenge the perceived pollution associated with commonly misunderstood diseases of the skin. They offer psychological and spiritual relief to their patients, who in many cases have been ostracized for years because of their skin's appearance and the religious sins associated with their disorders. Notably, the Ashram's patients are not the only ones who benefit from aușadh dān. Though not a return gift per se, the Aghori doctors gain something in return for the care they provide. They assuage the patients' social and psychological experience of being ill by symbolically absorbing their diseases, effectively displacing from patients to themselves the social and religious stigmas skin diseases have in some North Indian communities. The Aghori doctors' immunity to the diseases, despite their oft-perceived polluting contact with patients, is flaunted as a medal of Aghorī fearlessness and moral certitude. This contact 
empowers them. Purifying the sick, they uphold a putatively antinomian agenda that repudiates the restrictions of Hindu purity and pollution laws. The idea professed by Marriott in the 1970s about substance-code transference thus appears to be insignificant in the lives, work, and religious practice of the Ashram's Aghorī doctors.

At Mookkamangalam, the gift of āyurveda leads to bodily restoration, if not also social renewal for patients, their families and communities, which occurs with the reestablishment of health. Restoration is patently physical and, in less obvious ways, most likely also psychological. But in my experience rarely, if ever, has the vaidyan-rogi encounter entered into areas of moral renewal or spiritual cleansing for either the healer or the healed. The vaidyans at Mookkamangalam go to great lengths to separate their medical work from their religious practice, each of which, they insist, requires a unique frame of mind to perform and offers its own distinctive rewards.

\section{Who Gives What to Whom?}

How can we make sense of the vaidyans' overall behavior in the gifting of ayurveda to rogis at Mookkamangalam? What motivates them to do the work they do without remuneration and in a context that is potentially polluting? On the one hand, vaidyans and rogis at Mookkamangalam appear to be engaged in a classic Maussian gift exchange. The reciprocal nature of gift giving serves a basic social function that is, as Diana L. Eck has argued, "more than a gesture of generosity." It is an exchange that establishes interconnectedness between people and communities, creating "the very sinews of the body of society" (2013: 361). An exchange of knowledge about an unwell body opens the encounter at Mookkamangalam: first in the rogi's prestation of knowledge about her illness to the vaidyan, followed by the vaidyan's offering of a diagnosis and prescription to the rogi. For people familiar with visits to the doctor in the United States, this exchange would not be the end of it, since it's typically the offering of a diagnosis and treatment program, not the mere provision of a medical problem, that marks the first component of a quid pro quo of the kind that Mauss identified as gift giving in archaic societies. It usually follows that a physician ought to get paid for her work. Countless rogis at Mookkamangalam seem to believe as much, as their attempts to offer money to the vaidyans and their students illustrate. Yet for Mauss if a physician were to take a form of payment, that physician would not be truly gifting knowledge for long life. That is, if the ayurveda he offers is matched with a payment, the ayyurvedic knowledge is not a free, voluntary, or disinterested gift. According to the Maussian model, this kind of giving is constrained by social rules and obligations that are common in medical encounters in the United States today, where the things that are given (medicine and money) are based on a long-established system of reciprocity. If that is the system we are used to, we might expect that the vaidyan's gift of ayurveda should be met with a counter gift, such as a payment of some kind. But at Mookkamangalam the vaidyan neither receives nor requests this. 
Before attending to the matter of payment for services rendered, the absence of which calls up the topic of the so-called Indian gift, I hasten to point out that the knowledge being exchanged at Mookkamangalam is hardly symmetrical. The rogi offers individual, intimate, and experiential knowledge of her illness. This knowledge carries with it personal and social anxieties that affect the way and the extent to which she conveys her experience to the vaidyan. The vaidyan imparts knowledge bulwarked by years of study and professional activity, which is based on the collection of current and historical data provided by the rogi. This knowledge is etiological, prognostic, and therapeutic. Such a clear difference perhaps explains why a mere tit for tat is not adequate for most rogis, who expect to compensate the vaidyan's tat (medical knowhow) with some form of tit (typically money). There is also a sharp difference in what's at stake for the gift giver and the gift receiver in this relationship. The patient physically suffers and stands to gain a great dealhealth, reincorporation into her community, peace of mind-by overcoming an illness. But what does the physician stand to gain or lose? This question, I submit, is best understood in view of the vaidyan's decision not to accept counter gifts for the medical services he administers.

As we have seen, at Mookkamangalam the run-of-the-mill gift of ayurveda (in nonemergency situations) is tantamount to a gift of knowledge. In the field of Indian dāna, this aligns with the area of vidyā dāna, sometimes also known as a gift of learning (Agarwal 2010: 146-47). In the traditional Brāhmaṇical context, Manu held vidyā dāna "to be the supreme gift above other gifts of water, food, cows, clothes, sesame, gold and clarified butter" (Acharya 1996: 104). The twelfth century masterwork on dāna, Dānasāgara (Ocean of Gifting, 1168), by the second ruler of the Sena dynasty of Bengal, Ballālasena, extoled the virtuousness of various types of gift giving, including the gifting of land grants to Brāhmana communities for the advancement of Vedic learning and the gifting of knowledge from teachers to students (Bhattacharya 1953-56). ${ }^{8}$ Indeed, vidyā dāna is most often associated with education (Agarwal 2010: 101). Whenever I have asked the vaidyans at Mookkamangalam what constitutes the medicine they deal in, they have always told me that what they give rogis is simply knowledge-though, importantly, they prefer to use the term vijñana, which, like vidyā, also means "knowledge" in Malayalam and Sanskrit, though it implies a specifically practicable type of knowledge meant for concrete application. They regard vijñanna to be a special variety of the knowledge (veda) conducive to long life (âyus) that undergirds their practice. Meant to improve the quality of life of sick people, this knowledge also has a capacity to liberate and empower. Upon leaving the clinic with a kurippati ("prescription"), a rogi is equipped and educated to treat herself. From an observer's perspective, this appears to be a genuine gift, decidedly unlike do ut des, that's designed for a designated worthy recipient (supātra), the rogi, who leaves the clinic free of the obligation to return anything to the vaidyan.

Vaidyans at Mookkamangalam of course realize that most people expect to pay for healthcare. They also know that many of their patients have been seen by other

\footnotetext{
${ }^{8}$ Heim (2007) offers an excellent overview of the major compendia (nibandha) on dāna in Hinduism, Buddhism, and Jainism.
} 
doctors (often from diverse medical systems, such as biomedicine, Unānī, homeopathy, and Āyurveda) before they visit their clinic, and in those prior medical encounters they had to pay for the services they received. From the patient's perspective, why should the matter of a doctor's fee be any different if one visits a modern medical establishment or a Malayāli mana in the middle of a mango grove? It is here, in the frequently observed chasm separating the vaidyan's view and the rogi's view about the nature of exchange and reciprocity in the therapeutic context that a number of crucial questions emerge concerning the gift in theory and practice in India. Why aren't payments accepted for āyurvedic services offered at this clinic? Are there simply no types of payment that could match the offering of ayurveda adequately, such that a counter gift like money would in some way tarnish the gift of knowledge for long life? Do the vaidyans at Mookkamangalam understand the ayurveda they give to rogis to be unrequitable? When we attempt to address these questions, we confront features of the classical Indian theory of dana that directly run up against Mauss's theory of the gift.

A number of scholars have suggested ways that dāna departs from and resists Mauss's illustration of gift exchange, most notably on the matter of a recipient's obligation to reciprocate (Trautmann 1981; Parry 1986, 1994; Raheja 1988; Michaels 1997; Laidlaw 2000; Heim 2004; Ohnuma 2005; Copeman 2011; Eck 2013). For example, Reika Ohnuma observes that dāna theory in the three classical religions of India-Hinduism, Buddhism and Jainism- "agrees with Mauss that all ordinary gifts are reciprocal in nature, only to reject such gifts in favor of an asymmetrical, unreciprocated gift that bears fruit in the transcendent future, beyond the present realm of give-and-take" (2005: 106). Ohnuma draws on Thomas Trautmann's observation that the classical Dharmaśāstra theory of the gift "is a soteriology, not a sociology of reciprocity" (1981: 279), as it was for Mauss. At its core the Indian notion of dāna says the true gift is neither a part of the social web of reciprocity nor is it an act that prompts a return. There is no redistribution of resources with dāna. It pertains exclusively to questions of moral value. Because the relationship between giver and receiver is always asymmetrical, it creates what Maria Heim has called an "ethics of esteem" that fosters interpersonal respect and admiration toward the receiver."

According to the classical Dharmaśāstra model, gifts traditionally go to worthy recipients, which are invariably Brāhmaṇas and often renouncers (samnyāsin), such as Hindu holy men $(s \bar{a} d h u)$. Worthy recipients in Jainism are known as strivers (śramana), while in Buddhism the classical conception of "beggars," or monks or nuns (bhikșu or bhikșuṇ $)$, typify the quality of worthiness in a gift receiver. Ballālasena's Dānasāgara classifies worthy recipients according to moral qualities: they should be recognized by others, by socioreligious convention and through their conversation, to be well behaved, pure, and wise (Heim 2007: 198). In contemporary social practice, gift recipients who needn't give anything in return are often people who own nothing, or possess very little, and have removed themselves from the ebb and flow of commercial society (Eck 2013: 365-68). Lay

\footnotetext{
9 See Heim 2004, pages 144-47 concerning the "ethics of esteem" and page 74 regarding the interpersonal moral values encoded in dāna.
} 
Buddhists' daily offerings of food to monks and nuns, for example, or householder Hindus giving gifts of food and coins to the sea of $s \bar{a} d h u$ s at the Kumbh Melā readily come to mind. The monk and the $s \bar{a} d h u$, as Eck recently put it, are "renouncers [who] bear witness to a set of values they place over and against the markets and materialism of the culture at large" (2013: 368). According to the traditional view of dana, worthiness of the recipient signals perhaps the most critical element of the gift in both theory and practice.

In contrast, the gift of knowledge for long life offered by vaidyans at Mookkamangalam seems to place a different emphasis on what constitutes worthiness regarding gift reception: the worthy recipient is the patient, a person in need of a cure. Copeman's research on charitable blood donation (rakt dān) is instructive here. His study showed that contemporary forms of dāna in India like blood donation and philanthropy emphasize neediness rather than worthiness as the vital characteristic of a gift recipient (though he also notes that the two categories, worthiness and neediness, are not mutually exclusive). Copeman's research thus extends the classical view of dāna, in effect reformulating the notional value of worth to include need. A powerful result of this extension is that "accountability is built into dan." What's more, he continues, "efficacy is assured prior rather than subsequent to the gift," since by the criterion of neediness a person does not present a gift to someone for whom it is uncertain to provide some kind of benefit (Copeman 2011: 1064). In the āyurvedic context, the classical Sanskrit literature addresses the question of need by delimiting the types of patients who should and should not be treated. Are they persons whose treatment is apt to fail? Are they knowledgeable and able to follow instructions? Do they have resources to purchase the medicines they will need? Will they follow through with the prescribed medications and doses recommended by the physician? And so on. In this way the compilers of the literature of Āyurveda present numerous qualities of the needy patient suitable for treatment. Interestingly, at the end of the day, a patient's need might actually also reflect the needs of the physician. As Dagmar Wujastyk has shown,

[In the Sanskrit classics of Āyurveda] the medical authors' image of the patient is very much derived from the perspective of the physician's needs. Most of the patient's good characteristics - wealth, curability, obedience to the physician, and fearlessness-pertain to the physician's convenience: A good patient is one who makes the physician's job easy and worthwhile (2012: 58).

As a consequence, the Sanskrit medical classics are ambiguous and far from uniform from text to text about who the patient is. This is possibly due to the lack of specific case studies in the sources from the classical period. And apart from instances in which the compilers of the literature explored the patient narratively, crafting stories about the ways in which people become ill and recover from illness (Cerulli 2012: 147-60), when we look across the classical corpus as a whole, the literature offers precious few, often rather cursory and conflicting statements about the types of patients a physician should and should not treat (Dagmar Wujastyk 2012: 59). 
The gifting relationship between vaidyans and rogis at Mookkamangalam, much like the classical ideology of the Indian gift (dāna), appears to be unidirectional, moving from a gift giver to a worthy gift receiver, the latter of whom is not obliged (and not allowed) to make recompense for the gift received. But as we have seen, the gift of ayurveda moves from physician to patient. It stands the classical relationship of gift giver and gift receiver on its head by making neediness the primary criterion for receiving knowledge for long life (rather than or perhaps as a type of worthiness). How, then, can we make sense of the nature and role of the gift giver in this exchange, the Nambūtiri vaidyan, whose gratuitously given gift seems out of place in the professional practice of medicine? Those familiar with classical Hindu devotional literature might recall one of the most basic and well-known directives in Hinduism pertaining to the "ethic of the donor," which the god Kṛ̣na clarifies to the Pāndava warrior Arjuna in the Bhagavad Gìtā: one must comprehend what one's role on earth is (Eck 2013: 369). That is every person's duty, or dharma. Having learned that, one should renounce the desire for the fruits of one's actions in doing one's dharma: try to act selflessly, freely shaping one's actions as sacrificial offerings of devotion to a chosen deity, while forsaking the potential positive outcomes of one's deeds. In Malayalam, upekșikkuka is the verb used in this context, denoting to give up or forsake something, such as potential benefits that might return to oneself after giving a gift. It signals the disownment of something in the sense of relinquishing it from one's possession. At Mookkamangalam, upeksikkuka is an act of austerity, given that the vaidyans take nothing, neither goods nor money, in return for their gifting of knowledge to rogis. Yet it is more than just austerity. It is a veritable "relinquishment of...proprietary rights in the property" (Eck 2013: 370) of āyurvedic knowledge itself, insofar as they educate, equip, and empower rogis with an awareness of their bodies and a medical competency that enables them to treat themselves in the future. The knowledge a rogi presents is obviously not given unselfishly. He or she expects and in fact needs something in return. The vaidyan's dāna, however, appears to be quite the opposite, altruistic giving or generosity that falls within the ambit of Hindu, Buddhist, and Jain articulations of the giver of dāna, whose gift giving "forms a basis for further moral and spiritual development" (Harvey 2000: 61). The rogi at Mookkamangalam is a worthy recipient by virtue of her need, while the vaidyan is a sacrificer, a seeker, a striver for moral development by virtue of his or her gratis gift of knowledge to properly designated recipients.

\section{Conclusions: What Gives?}

The suggestion that a gift might be truly nonreciprocal is bound to raise suspicions. What is the point of engaging in āyurvedic practice if there isn't an obvious reimbursement for seeing and treating patients? (It's worth noting that the Mookkamangalam vaidyans also do not accept money for their gurukulam training of students.) I have asked the vaidyans at Mookkamangalam this question many times, and every time I've been told the Sanskrit medical classics recommend that $\bar{A}$ yurveda should be practiced in this way. While it is true that the Sanskrit classics 
say this, in more ways than one, not all of the sources are in agreement about the policy of offering medical services freely. All the same, this is the interpretation of the classics regularly invoked by the vaidyans at Mookkamangalam and their students. Whenever I broach the issue, references quickly abound to sections in the Carakasamhitā that explicitly identify medical quacks as those who practice medicine without much knowledge and do so unambiguously for monetary gain. Dagmar Wujastyk's research on medical ethics in Sanskrit medical literature suggests that the Carakasamhitā is the central source differentiating so-called ayyurvedic quacks from bona fide vaidyas in the classical period. There are two types of quacks, she concludes: "one is a deluded person who wrongly, though perhaps innocently, believes himself to be a physician. The other is someone who knows full well that he lacks knowledge and skill yet viciously persists in practicing medicine" (Dagmar Wujastyk 2012: 51). In either case, the result is that the patient suffers at the hands of a quack, while a quack nonetheless takes payment for his failure and, incongruously bragging about his abilities despite his inability to heal, he blames the patient for the poor outcome. Dominik Wujastyk has further shown that the Carakasamhitā clearly specifies a fraudulent āyurvedic doctor as one who, after his attempted therapy fails, points "out that it was the patient himself who lacked equipment, helpers, and the right attitude" (1993: 762). Fault and failure are always placed on the patient wherever quacks are concerned.

There is also tension in the Sanskrit literature about the relationship of "genuine" ayyurvedic practice to livelihood and the acquisition of money for the work an àyurvedic physician does. The Carakasamhitā contains statements that could be adduced to support arguments both for and against the receipt of money for dispensing āyurvedic treatment. At best, we might safely say the compilers of this compendium, often considered the literary cornerstone of Āyurveda (compiled around the turn of the common era), were ambivalent, or quite possibly their views changed over the course of time during which the text was assembled, about whether or not physicians should accept money. They were quite unequivocal, however, in stating that money should not be the physician's primary motivation for offering treatment. Addressing the issue with a bit more conviction about the physician-patient exchange, a medieval Sanskrit text, Bhāvamiśra's Bhāvaprakāśa, states that "one who does not recompense for bodily treatment is a fool," suggesting that the physician should not only be paid for the good works he or she does but also that the physician should be recognized as doing good work (Dagmar Wujastyk 2012: 121). In the earlier classical sources, criteria are occasionally set about who should and should not receive payment for their work-quacks or genuine vaidyas. Often it boils down to the social class (varna) of the physician.

In the opening section of the Carakasamhitā, a passage states that only physicians of the Vaisya class should practice Āyurveda for money, whereas Brāhmaṇas and Kṣatriyas should practice for free (Carakasaṃhitā, Sūtrasthāna 30.29). And yet, contrariwise, Kenneth G. Zysk (1991: 45) has written about remarks of the fifth century CE Chinese traveler in India, Faxian, describing Vaisya families in Pāțaliputra dispensing "charity and medicine" to the poor, diseased, and handicapped that are suggestive of the charitable practice of freely gifting ayurveda without compensation. It's well known the classical sources of Āyurveda as we have 
them today are products of numerous revisions, interpolations, and emendations that occurred over centuries, and, as shown above, they often present inconsistencies about things that would fall under the categorical umbrella of professional etiquette. So it is not clear if, even in the case of Brāhmana physicians, the compilers of the Carakasamhitā "envisaged a direct transaction between patient and physician, that is, [whether]...the physician received payment directly from the patient for each treatment" or if payment might have been made and accepted by another means (Dagmar Wujastyk 2012: 119). ${ }^{10}$

If the Carakasamhitā presents too many positions on the association of āyurvedic practice and monetary gain to draw definitive conclusions about whether or not the gift of knowledge for long life should be gratis or a proper source of one's livelihood, the compilers of the compendium were relatively consistent and clear about why a person would want to pursue āyurvedic medicine as a profession.

The physician striving for the highest dharma should save from pain all patients like they were his own sons. Single-mindedly fixed on dharma and eager for everlasting life, the great sages revealed knowledge for long life for the sake of religious merit and for the sake of wealth and pleasure. He who practices medicine neither for wealth nor pleasure, but rather with compassion for all creatures, surpasses everyone. But the one who deals in the business of medicine for livelihood, he abandons the heap of gold and obtains a pile of manure (Carakasaṃhitā, Cikitsāsthāna 1.56-59). ${ }^{11}$

This passage is remarkable in the context of the present discussion for its use of the phrase "for the sake of wealth and pleasure," which comes from the Sanskrit phrase cārthakāmārtham. This edition of the passage is found in Jādavji Trikamji Ācārya's edition of the Carakasamhita , which is widely recognized as the most dependable version of the compendium available today. Yet the arguably best-known English translation of the Carakasamhitā, edited and translated by P. V. Sharma, relies on a variant reading, nārthakāmärtham, which means "not for the sake of wealth and pleasure" (Dagmar Wujastyk 2012: 214n409; emphasis in original). Variant readings are often par for the course when reading classical Sanskrit texts, and the literature of Āyurveda is no exception in this regard. The example of the variants of this passage alone, setting aside the possibility of scribal errors in the transmission of this early section of the Cikitsāsthāna, illustrates the philological challenges involved in defining a particular work-related component of the medical profession in classical India. But we must work with what is available. So we may take these two variants as suggesting, on the Sharma reading, that dharma, the multifaceted

\footnotetext{
${ }^{10}$ Dagmar Wujastyk also cites examples from nonmedical Sanskrit texts like Kauțilya's Arthaśāstra and a Tamil inscription in the Viṣnu temple of Veñkateśa-Perumāḷ at Tirumukkūḍal as evidence that payment to physicians in the form of land grants and royal patronage were also ways for āyurvedic physicians to benefit from their work.

11 bhiṣag apy āturān sarvān svasutān iva yatnavān I ābādhebhyo hi saṃrakședicchan dharmamanuttamam || 56 || dharmārtham cārthakāmārtham āyurveda maharșibhih | prakāśito dharmaparair icchadbhih sthānam akșaram || 57 || nārthārtham nāpi kāmārtham atha bhütadayām prati | vartate yaś cikitsāyām sa sarvam ativartate || 58 || kurvate ye tu vrttyartham cikitsāpanyavikrayam | te hitvā kāñcanam rāsím pāmśsurāśimupāsate \|| 59 ॥
} 
Hindu principle marking a person's social-legal-religious duties, is the primary aim of the ayyurvedic physician (here labeled with the title of bhisaj), while wealth (artha) and pleasure (kāma) are dissociated from the practice of the unexcelled physician. Trikamji's reading instead brings the original intention of the ayyurvedic physician's practice directly within the ambit of the fundamental Hindu doctrine of purușārtha, which outlines the four proper aims of human life-kāma, artha, dharma, and moksa. ${ }^{12}$ The choice to follow either reading reveals a conviction about where one positions the dissemination of knowledge for long life along a spectrum that holds medicine-as-vocation at one pole and medicine-as-livelihood at the other.

The term dharma lies at the heart of the notion of medicine-as-vocation in the Carakasamhitā. The physician who strives for the "highest dharma" (dharmamanuttamam) in the foregoing passage is marked by "compassion for all beings" (bhütadayām). The Carakasamnhitā's appeal to compassion as the physician's "duty" (dharma), rather than a financial motivation, is suggestive of the long-held hypothesis in secondary literature on Āyurveda that the Sanskrit medical classics exhibit a discernable Buddhist influence. ${ }^{13}$ Of particular relevance are the Four Noble Truths (catvāri äryasatyāni), which some Buddhologists have argued encapsulate the Buddha's teaching on compassion-namely, the wish that all beings be free from suffering. A common argument, initially put forth by Hendrik Kern in Manual of Indian Buddhism (1896), is that the Four Noble Truths were known among the compilers of the Carakasamhitā, evidenced by their resemblance to a fourfold division of medical knowledge in the text. Compare:

Four Noble Truths: (1) all existence is duhkha (dissatisfaction or suffering); (2) the cause of duhkha is thirst; (3) putting an end to thirst stops duhkha; (4) the way to eliminate duhkha is by following the Eightfold Path.

The best physician possesses the fourfold knowledge of cause, symptomatology, healing, and prevention of diseases; he is fit for [doctoring] the king (Carakasaṃitā, Sūtrasthāna 9.19). ${ }^{14}$

The likeness is perhaps only slight. Zysk has investigated Kern's claim, noting several serious flaws in his argument. Following Albrecht Welzer, Zysk also gives a sense of the vastness of the trajectory of scholarship among Buddhologists who "blindly followed" Kern's erroneous claim (Zysk 1991: 38, 144-45; also see Engler 2003: 426n6). A different passage in the Carakasamhitā, however, could be read as drawing on the concept of suffering (duhkha) in the Four Noble Truths to articulate an early philosophical position in Āyurveda on human existence:

\footnotetext{
${ }^{12}$ The fourth aim in this list, mokșa, "release" from the cycle of rebirth and redeath of samsāra, is infrequently discussed in classical ayyurvedic literature, whereas the first three, referred to as the trivarga, the "three things" or "three conditions," are discussed at length (see, for example, Cerulli 2012: 30, 136$40,153,161-65)$.

${ }^{13}$ In India many scholars have denied there is a noteworthy Buddhist influence on the basis of an assumption that the earliest medical source, the Carakasamhitä, might predate the life of the Buddha, and it is the Carakasamhitā that informs the other classical treatises (Meulenbeld 1999-2002, 1A: 110). That said, this is neither the prevailing attitude of one of India's most prolific historians of medicine, P. V. Sharma, nor is it the general attitude among scholars outside of India.

${ }^{14}$ hetau linge praśamane rogāṇāmapunarbhave | jñānam caturvidham yasya sa rājārho bhiṣaktamah \|| $19 \|$
} 
Everything that has a cause is suffering. It is not one's own. It is temporary. It is not created by the self. Yet it arises as one's own possession. Once the true knowledge that I am not this [suffering] and this [suffering] is not mine arises, with that [knowledge] the wise man overcomes all suffering (Carakasamhitā, Śārīrasthāna 1.152-153). ${ }^{15}$

The Buddhist ideal of offering compassion to all living beings-whose lives are indelibly marked by suffering-lends itself nicely to the present discussion about gratuitous gifting of medical knowledge. The absence of any recompense, indeed the insistence that there be no repayment for medical services, suggests the Mookkamangalam vaidyans view their work as vocational. The gifting of ayurveda is done for the simple, if magnanimous, purpose of helping people overcome and deal with suffering.

Given their unswerving responses to my questioning year after year about not accepting payment for their gifting of ayurveda to rogis, it is perhaps unsurprising that they see their work à la the Sharma text, as a dhārmic obligation in a socioethical sense, meant to help the ailing and infirm. Their patients are patently suffering and in need of compassion. That the vaidyans take no money might speak to their self-awareness as bona fide physicians of Āyurveda in the august vision of the Sanskrit medical classics. Yet it must also be noted that the family of vaidyans at Mookkamangalam has other sources of revenue to make ends meet, which thus offers an explanation-albeit a potentially cynical one-for their refusal to accept payment for their medical work. Still, however one views this economic reality, it only partly speaks to why the vaidyans apparently defy the inherent, if socially unstated, expectation people have to receive gifts after giving them and to give gifts after receiving them. This is the social circumstance of do ut des or, in Mauss's terms, the "total services" of human societies, archaic and modern that characterize gift exchange (1990: 13-14). In Malayāli society this kind of exchange is known as sammānam, a gift that is offered between equals in the sense of trade or mundane

\footnotetext{
15 sarvam kāraṇavadduḥhamasvam cānityameva | na cātmakṛtakam taddhi tatra cotpadyate svatā ॥| 152 ॥ yāvannotpadyate satyā buddhirnaitadaham yayā | naitan mameti vijñāya jñah sarvamativartate || 153 ||

Additional evidence often adduced in support of a Buddhist influence on Āyurveda is that the Carakasamhitā uses a number of terms in a manner similar to those found in Buddhist literature, such as: manas and sattva are treated synonymously; the notion that life (āyus) begins with the combination of śarīra, indriya, sattva, and àtman; the emphasis on perception (pratyakșa) and inference (anumāna) as means for the acquisition of valid knowledge; among several others (Meulenbeld 1999-2002, 1A: 11011; Sharma 1992: 182-84). The medical author Vāgbhața, whose name is given as the author of the Aștāingahrdayasamnitā and the Aștāngasamgrahasamnhitā (though both sources were not likely written by the same person), is often said to have been the most heavily influenced by Buddhism among the classical Indian medical authors. Vāgbhața mentions the "middle way" in the Aștāngahrdayasamhitā, and he refers to several names known in Buddhist literature, such as his first teacher, Avalokita (Aștāingasamgraha, Sūtrasthāna 28.34, Cikitsāsthāna 2.144, Uttarasthāna 8.57; Aștāingahrdaya, Uttarasthāna 5.50), Bhaișajyaguru (Aștāñgasaṃraha, Sūtrasthāna 27.12-13; Aștāingahṛdaya, Sūtrasthāna 18.17-18), Avalokiteśvara (Aștāñgasaṃraha, Sūtrasthāna 8.59), Ratnaketu (Aștāingasaṃgraha, Uttarasthāna 1.19), and others. Other indications that the works ascribed to Vāgbhața are Buddhist in character include the use of the title arhant for Bhaisajyaguru (this is found in both the Astāingahrdaya and Asțāingasamgraha); the mention of a healing figure (dhāriṇ̂) who prepares a collyrium paste to purify the three eyes (of prajñ $\bar{a}$, jñ̄ana, and vijñāna) is referred to as a "Tathāgata" and "Samyaksaṃbuddha" (Aștāingasamgraha, Sūtrasthāna 58-61); and the Buddhist deity Tāra is also mentioned (Aștāingasaṃraha, Cikitsāsthāna 21.135; Aș̣̂̄àngahṛdaya, Cikitsāthāna 19.98).
} 
exchange. Because the Indian gift, dāna, is thought to contain the "spirit" of the person who gives it, the gift is understood as a kind of self-sacrifice. Just as the sacrificial victim stands in for the sacrificer, "so the gift is a surrogate for the donor," for which "no return of any earthly kind is countenanced and even an increment to the prestige of the donor weakens the gift" (Parry 1986: 461).

By gifting knowledge for long life to those who need it, does the vaidyan engage in dānadharma? Of the two overarching markers of dānadharma-which Michaels has divvied into seven categories drawn from a collection of Dharmaśāstra textsvaidyans at Mookkamangalam follow one and contravene the other (1997: 249-51). That is, on the one hand, the gift of knowledge for long life is nonreciprocal in the classical dānadharma sense. It must be unidirectional for the reasons noted above, not the least of which is the opinion that âyurvedic treatment administered primarily for compensation is regarded as quackery. On the other hand, Parry has suggested that in the Indian context "the donor should seek out the reluctant recipient and give freely" because "the genuine gift is never solicited" by a gift recipient (1986: 461). On this point the vaidyan's gift of knowledge at Mookkamangalam doesn't quite correspond, in large part because the movement of prestations appears to run counter to the examples in the literature on dāna, where sanctified or learned persons reluctantly receive gifts they are not expected to reciprocate. In the present case, rogis receive without reciprocating. Mookkamangalam vaidyans do not lobby for patients, and their patients naturally are not averse to receiving the vaidyans' knowledge. All the same, these exchanges still evoke the so-called Indian gift, since ayurveda is given gratuitously, without expectation of recompense among people united in an asymmetrical relationship. Neediness (rather than worthiness) is notably the basic criterion of the gift receiver. And yet, because the receiver selfishly pursues the gift giver's ayurveda, the Mookkamangalam case defies this aspect of the Indian gift. This case of giving and receiving, in other words, is far from straightforward.

To move again from the practice of gifting knowledge to the theoretical presentation of the physician-patient exchange in the classical literature, in the Carakasamhitā we also find the following: "There is no gift to compare with the gift of life. The practitioner of medicine who believes that his highest calling is the care of others achieves the highest happiness. He fulfils himself' (Carakasamnitā, Cikitsāsthāna 1.60-62; Dominik Wujastyk 1993: 762). This passage suggests that by virtue of the very ability to give the gift of medicine a vaidyan is compensated in a way. It is reasonable to ask whether or not fulfillment and happiness qualify as return gifts for the gift of ayurveda. This question in turn rouses other questions and points to other avenues for further study concerning prestation and the gift in ayyurvedic theory and practice. For example, what is the relationship between the emotional and moral outcomes experienced, perhaps even pursued, by the vaidyan who gifts knowledge for long life free of charge? Do the rewards of happiness and fulfillment in some way lessen the force of the free gifting of knowledge for long life? Do these rewards undermine the component of classical dana ideology in the ayyurvedic exchange of knowledge between physicians and patients? Moreover, who or what gives these gifts to the vaidyan in exchange for the gift of knowledge for 
long life? Are they not self-generating according to the aforementioned quote from the Carakasamhitā?

An investigation of ayurveda as a gift illustrates the complicated and fluid interplay of classical textual traditions and present-day practices among Malayāḷi vaidyans. While the physicians at Mookkamangalam acknowledge and abide by certain millennia-old notions of exchange that bring together socioreligious views about dharma and professional standards concerning remuneration and āyurvedic practice, when textual theory merges with clinical necessity, they rarely reify textual injunctions in Sanskrit texts in their daily work. Here, as Copeman observed in North India, we see that in spite of attempts to interpret the gift according to "processes of systematization and instrumentalization" based on scenarios proposed in texts, each instance of gift exchange is not "reducible to or definable in terms of these processes solely" (2011: 1093). From this an important methodological truism surfaces, and it's worth restating: ethnographic examination enriches philological inquiry. Joining fieldwork and philology encourages analytical equipoise and eschews the liability of ascribing undue or rigid influence to classical texts in people's everyday lives. When context sensitive social categories underline an exploratory theory like the gift and categories such as worthiness, recipients, reciprocity, and so on, a polythetic study that examines how people think and say they use classical texts, as well as how they actually use them (or don't use them), in their day-to-day activities is indispensable.

It is true that Mookkamangalam's vaidyans routinely appeal to classical Sanskrit texts to explain and justify their work. Yet, it's equally true that they invoke these sources primarily as fountainheads to be extended and adapted via impromptu interpretation and practice, using vernacular ideas and idioms, according to each patient's needs. In other words, if the texts' influence is foundational, their implementation is mutable. Hence, although students at Mookkamangalam learn many of the topics covered in Āyurveda's classical sources, from botany to disease causation, doctorly etiquette to the impact of the environment on human welfare, and much more, their most important lessons pertain to the epistemological agenda outlined in the texts. Textbook theory and experiential practice are complementary. They have been yoked for generations at Mookkamangalam, and they continue to be conveyed that way today. By listening to and observing the vaidyans, students learn techniques for comprehending a range of patient conditions and medical situations and how to manage them. The texts postulate ways to organize knowledge and think through medical problems that is both methodical and supple and serves students well when they leave the gurukulam and attend to patients on their own.

With Mauss's theory as the measure used to query gift exchange among classically trained Malayāli vaidyans, the practice of texts has emerged as a vital component of modern-day āyurvedic practice. Scholars have known for a long time that texts are important in Indian culture and history. Contemporary ethnographic studies like the one offered here, however, speak to an essential point on which their importance depends. It depends on the people and communities utilizing them. It depends on which texts are used, for which reasons, and at which times. When we observe the vaidyans at Mookkamangalam today, the question of dana cannot be reducible to a case of sāstric literalism, therefore. These physicians give their 
knowledge freely, suggesting the classical principle of dāna and evoking Mauss's famed concessional footnote about the Indian gift. And yet, gifting knowledge for long life, though buttressed amply by (sometimes conflicting) śāstric precedents, suggests that the so-called Indian gift too, as a theory of human interaction, is prone to generalization. The gifting of knowledge for long life is an Indian gift, to be sure. Accordingly, it is an exception to Mauss's general theory. As we have seen, it is additionally unique among classical Indian models of dāna. Adding nuance to Mauss's theory and the Indian ideal, in the āyurvedic context the gift takes us away from the primarily religious domain of classical dānadharma in Hinduism, Buddhism, and Jainism, which posits a unidirectional movement of gifts from laity to mendicants, and it opens up the the Indian gift to social relationships of a more professional, mundane nature.

Acknowledgments Thanks to Miriam Benteler for her collaboration and encouragement to produce this special volume of IJHS. Miriam and I co-convened a panel on the gift in 2014 in Tallinn, Estonia for the 13th annual conference of the European Association of Social Anthropologists, which was the impetus for this project. Accordingly, thanks also go to the presenters on our panel, from which two papers (Rolf Goesbeck and Karin Polit) have been revised for this volume. Many thanks go to my colleagues, friends, and informants in Kerala for their generosity and spirited conversation. And lastly, I thank the John Simon Guggenheim Memorial Foundation for supporting two stretches of fieldwork on which this research is based and the time that went into editing this volume.

\section{References}

Acharya, Poromesh. 1996. "Indigenous Education and Brahminical Hegemony in Bengal." In Nigel Crook, ed., The Transmission of Knowledge in South Asia: Essays on Education, Religion, History, and Politics, 98-118. New Delhi: Oxford University Press.

Agarwal, Sanjay. 2010. Daan and Other Giving Traditions in India: The Forgotten Pot of Gold. New Delhi: AcountAid India.

Barrett, Ron. 2008. Aghor Medicine: Pollution, Death, and Healing in Northern India. Berkeley: University of California Press.

Benteler, Miriam. 2014. Shared Values: Hierarchy and Affinity in a Latin Catholic Community of South India. New Delhi: Manohar.

Bhattacharya, Bhabatosh, ed. 1953-56. Dānasāgara of Ballālasena. Biblioteca Indica, 1563, 1567, 1569, 1573. Calcutta: Asiatic Society.

Bourdieu, Pierre. 1998 [1994]. Practical Reason: On the Theory of Action (trans. Randal Johnson, and others). Standford: Stanford University Press.

Cerulli, Anthony. 2012. Somatic Lessons: Narrating Patienthood and Illness in Indian Medical Literature. Albany: State University of New York Press.

Copeman, Jacob. 2011. "The Gift and Its Forms of Life in Contemporary India." Modern Asian Studies 45, 5: 1051-94.

Eck, Diana L. 2013. "The Religious Gift: Hindu, Buddhist, and Jain Perspectives on Dana." Social Research: An International Quarterly 80, 2: 359-79.

Engler, Steven. 2003. “' 'Science' vs. 'Religion' in Classical Ayurveda.” Numen 50, 4: 416-63.

Harvey, Peter. 2000. An Introduction to Buddhist Ethics: Foundations, Values and Issues. Cambridge: Cambridge University Press.

Heim, Maria. 2004. Theories of the Gift in South Asia: Hindu, Buddhist, and Jain Reflection on Dāna. London: Routledge.

Heim, Maria. 2007. "Dāna as a Moral Category." In Purushottama Bilimoria, Joseph Prabhu, and Renuka Sharma, eds., Indian Ethics. Volume 1: Classical Traditions and Contemporary Challenges, 191209. Burlington: Ashgate.

Kern, H. 1896. Manual of Indian Buddhism. Strassburg: Verlag Von Karl J. Trūbner. 
Laidlaw, James. 2000. "A Free Gift Makes No Friends." The Journal of the Royal Anthropological Institute 6, 4: 617-34.

Marriott, McKim. 1976. "Hindu Transactions: Diversity Without Dualism." In Bruce Kapferer, ed., Transaction and Meaning: Directions in the Anthropology of Exchange and Symbolic Behavior, 10942. Philadelphia: Institute for the Study of Human Issues.

Mauss, Marcel. 1923-24. "Essai sur le don: forme et raison de l'échange dans les sociétés archaïques." L'Année Sociologique (ns) 1: 30-186.

Mauss, Marcel. 1990 [1923-24]. The Gift: The Form and Reason for Exchange in Archaic Societies (trans. W. D. Halls). New York: W.W. Norton.

Menon, A. Sreedhara. 1979. Social and Cultural History of Kerala. Bangalore: Sterling Publishers.

Meulenbeld, G. Jan. 1999-2002. A History of Indian Medical Literature. 5 volumes. Groningen: E. Forsten.

Michaels, Axel. 1997. "Gift and Return Gift, Greeting and Return Greeting in India: On a Consequential Footnote by Marcel Mauss." Numen 44, 3: 242-69.

Ohnuma, Reiko. 2005. "Gift." In Donald S. Lopez, Jr., ed., Critical Terms for the Study of Buddhism, 10323. Chicago: University of Chicago Press.

Olivelle, Patrick. 2017. "The Medical Profession in Ancient India: Its Social, Religious, and Legal Status." eJournal of Indian Medicine 9, 1: 1-21.

Parry, Jonathan. 1986. "The Gift, the Indian Gift and the 'Indian Gift'." Man (ns) 21, 3: 453-73.

Parry, Jonathan P. 1994. Death in Banaras. Cambridge: Cambridge University Press.

Raheja, Gloria Goodwin. 1988. The Poison in the Gift: Ritual, Prestation, and the Dominant Caste in a North Indian Village. Chicago: University of Chicago Press.

Sharma, Priya Vrat, ed. 1992. History of Medicine in India: From Antiquity to 1000 A.D. New Delhi: Indian National Science Academy.

Sharma, Priya Vrat, ed. and trans. 2003 [1981-94]. Caraka-Saṃitā: Agniveśa’s Treatise Refined and Annotated by Caraka and Redacted by Dṛdhabala (Text with English Translation). 4 volumes. Varanasi: Chaukhambha Orientalia.

Trautmann, Thomas R. 1981. Dravidian Kinship. Cambridge: Cambridge University Press.

Trikamji Ācārya, Jādavji, ed. 1992 [1941]. Carakasaṃhitā of Agniveśa, with the Āyurveda-Dīpikā Commentary of Cakrapānidatta. New Delhi: Munshiram Manoharlal.

Wujastyk, Dagmar. 2012. Well-Mannered Medicine: Medical Ethics and Etiquette in Classical Ayurveda. New York: Oxford University Press.

Wujastyk, Dominik. 1993. "Indian Medicine." In W. F. Bynum and Roy Porter, eds., Companion Encyclopedia of the History of Medicine, 1: 755-78. London: Routledge.

Zysk, Kenneth G. 1991. Asceticism and Healing in Ancient India: Medicine in the Buddhist Monastery. New York: Oxford University Press. 